\title{
Flora of Singapore precursors, 17: Clarification of some names in the genus Calophyllum as known in Singapore
}

\author{
W.W. Seah ${ }^{1}$, S.M.X. Hung ${ }^{2} \&$ K.Y. Chong ${ }^{2}$ \\ ${ }^{1}$ Singapore Botanic Gardens, National Parks Board, \\ 1 Cluny Road, 259569 Singapore \\ seahweiwei@gmail.com \\ ${ }^{2}$ Department of Biological Sciences, National University of Singapore, \\ 14 Science Drive 4, 117543 Singapore
}

\begin{abstract}
The species, Calophyllum soulattri, is found to have been wrongly included in Singapore's native flora. The name Calophyllum wallichianum var. wallichianum is also found to have been misapplied to a taxon in Singapore and should rather be called Calophyllum rufigemmatum. The nomenclatural history and problems of both taxa are discussed in this paper.
\end{abstract}

Keywords. Calophyllaceae, C. rufigemmatum, C. wallichianum, Clusiaceae, nomenclature, taxonomy

\section{Introduction}

The genus Calophyllum L. had long been included in the family Clusiaceae Lindl. (alternate name: Guttiferae Juss.) until recent molecular phylogenetic studies showed that it was necessary to transfer it, along with several other genera (e.g. Kayea Wall., Mammea L. and Mesua L.) from the Clusiaceae subfamily Kielmeyeroideae, to the reinstated family Calophyllaceae J.Agardh (APG III, 2009; Wurdack \& Davis, 2009). The genus was last revised by Stevens (1980) for the Old World, including the IndoMalesian region, where it is mainly distributed. It now comprises about 190 recognised species worldwide (Stevens, 2001 onwards; Ramesh et al., 2012).

In his revision of the genus, Stevens (1980) reported 17 taxa-including an unnamed species - for Singapore. Following his account, several authors (Keng, 1990; Turner, 1993; Chong et al., 2009) enumerated the species of the genus and recorded different numbers of taxa for Singapore (Table 1). Among these taxa, Calophyllum soulattri Burm.f. is observed to have first been incorrectly included in Singapore's native flora by Keng (1990) and subsequent authors followed suit. On the other hand, the name Calophyllum wallichianum Planch. \& Triana var. wallichianum is discovered to have been misapplied by LaFrankie et al. (2005) to a taxon in the Singapore flora which is actually Calophyllum rufigemmatum M.R.Hend. \& Wyatt-Sm. ex P.F.Stevens. The name was also used by Tan et al. (2008) and Chong et al. (2009). This paper discusses the nomenclatural history and problems of these two taxa. All herbarium acronyms used follow Thiers (continuously updated). 
Table 1. List of Calophyllum species native to Singapore as reported by various authors.

\begin{tabular}{|c|c|c|c|c|c|}
\hline No. & Species & $\begin{array}{l}\text { Stevens } \\
(\mathbf{1 9 8 0 )}\end{array}$ & $\begin{array}{l}\text { Keng } \\
\text { (1990) }\end{array}$ & $\begin{array}{l}\text { Turner } \\
\text { (1993) }\end{array}$ & $\begin{array}{l}\text { Chong } \\
\text { et al. } \\
(2009)\end{array}$ \\
\hline 1 & Calophyllum biflorum M.R.Hend. \& Wyatt-Sm. & $\checkmark$ & $\checkmark$ & $\checkmark$ & $\checkmark$ \\
\hline 2 & $\begin{array}{l}\text { Calophyllum calaba L. var. bracteatum (Wight) } \\
\text { P.F.Stevens }\end{array}$ & $\checkmark$ & $\checkmark$ & $\checkmark$ & $\checkmark$ \\
\hline 3 & $\begin{array}{l}\text { Calophyllum costulatum M.R.Hend. \& Wyatt- } \\
\text { Sm. }\end{array}$ & $\checkmark$ & $\checkmark$ & $\checkmark$ & $\checkmark$ \\
\hline 4 & Calophyllum dispar P.F.Stevens & $\checkmark$ & $\checkmark$ & $\checkmark$ & $\checkmark$ \\
\hline 5 & Calophyllum ferrugineum Ridl. & $\checkmark$ & $\checkmark$ & $\checkmark$ & $\checkmark$ \\
\hline 6 & Calophyllum inophyllum $\mathrm{L}$. & $\checkmark$ & $\checkmark$ & $\checkmark$ & $\checkmark$ \\
\hline 7 & $\begin{array}{l}\text { Calophyllum lanigerum Miq. var. } \\
\text { austrocoriaceum (Whitmore) P.F.Stevens }\end{array}$ & $\checkmark$ & $\checkmark$ & $\checkmark$ & $\checkmark$ \\
\hline 8 & Calophyllum macrocarpum Hook.f. & $\checkmark$ & $\checkmark$ & $\checkmark$ & $\checkmark$ \\
\hline 9 & Calophyllum pulcherrimum Wall. ex Choisy & $\checkmark$ & $\checkmark$ & $\checkmark$ & $\checkmark$ \\
\hline 10 & Calophyllum rigidum Miq. & $\checkmark$ & $\checkmark$ & $\checkmark$ & $\checkmark$ \\
\hline 11 & $\begin{array}{l}\text { Calophyllum rubiginosum M.R.Hend. \& Wyatt- } \\
\text { Sm. }\end{array}$ & $\checkmark$ & $\checkmark$ & $\checkmark$ & $\checkmark$ \\
\hline 12 & $\begin{array}{l}\text { Calophyllum rufigemmatum M.R.Hend. \& } \\
\text { Wyatt-Sm. ex P.F.Stevens }\end{array}$ & $\checkmark$ & $\checkmark$ & $\checkmark$ & $\checkmark$ \\
\hline 13 & Calophyllum soulattri Burm.f. & & $\checkmark$ & $\checkmark$ & $\checkmark$ \\
\hline 14 & Calophyllum sundaicum P.F.Stevens & $\checkmark$ & $\checkmark$ & $\checkmark$ & $\checkmark$ \\
\hline 15 & Calophyllum tetrapterum Miq. & $\checkmark$ & $\checkmark$ & $\checkmark$ & $\checkmark$ \\
\hline 16 & Calophyllum teysmannii Miq. & $\checkmark$ & $\checkmark$ & $\checkmark$ & $\checkmark$ \\
\hline 17 & $\begin{array}{l}\text { Calophyllum wallichianum Planch. \& Triana } \\
\text { var. incrassatum (M.R.Hend. \& Wyatt-Sm.) } \\
\text { P.F.Stevens }\end{array}$ & $\checkmark$ & $\checkmark$ & $\checkmark$ & $\checkmark$ \\
\hline 18 & $\begin{array}{l}\text { Calophyllum wallichianum Planch. \& Triana } \\
\text { var. wallichianum }\end{array}$ & & & & $\checkmark$ \\
\hline 19 & Calophyllum sp. 151 & $\checkmark$ & & $\checkmark$ & \\
\hline
\end{tabular}

\section{Calophyllum soulattri, not a native in Singapore}

Calophyllum soulattri was consistently documented under the misapplied name Calophyllum spectabile Willd. by many early authors, including "Ridley, F1. Malay Penin. 1: 185. 1922, pro parte ..." according to Stevens (1980). Calophyllum spectabile auct. non Willd. sensu Ridley (1922) (=C. soulattri) was said to be distributed in "Singapore, Malacca. Penang (Wall. 4843), Pahang on Gunong Tahan; Kwantan (Foxworthy). Distrib. Malay islands and Cochin-China.”. Ridley (1900) previously 
reported the taxon's localities in Singapore as "Gardens Jungle, Bukit Timah, Selitar". Subsequently, Keng (1990) listed Calophyllum soulattri as being recorded from "Gardens Jungle, Bukit Timah, Seletar". Keng (1990) based his taxonomic concepts of Calophyllum spp. on Stevens (1980), as explained in a footnote, but he likely also referenced the distribution statement from Ridley (1900) as Stevens (1980) did not mention that $C$. soulattri was distributed in Singapore. Afterwards, Turner (1993) catalogued Calophyllum soulattri with citations of Stevens (1980) and Keng (1990) as well as the synonym: "C. spectabile auct. non WILLD.; RIDLEY, J. Str. Br. R. As. Soc. 33 (1900) 47; RIDLEY, Fl. Mal. Pen. I (1922) 185, p.p.”. Chew et al. (1997) also documented the species based on "observations from NParks staff and NRS unpublished checklists". Tan et al. (2008) assessed the conservation status of the species as Critically Endangered in Singapore. Consequently, Chong et al. (2009) followed the earlier authors and included this species in their checklist. All of the above suggest that Calophyllum soulattri could be found in Singapore.

However, as mentioned above, Stevens (1980) did not specifically mention any collections or observations of Calophyllum soulattri in Singapore. He stated that the species can be found from Vietnam through parts of Southeast Asia (including Thailand, Cambodia, and Peninsular Malaysia) and Borneo, to Australia as well as the Solomon Islands, and Palau Island. He also did not cite Ridley (1900) under the synonymy of Calophyllum soulattri. Furthermore, no historical or recent specimens in the Singapore Botanic Gardens Herbarium (SING) collection were found to be determined as Calophyllum soulattri from the three localities mentioned in Ridley (1900). Instead, a specimen labelled "Calophyllum spectabile" collected from "Gardens Jungle" in the 1880s was confirmed as Calophyllum ferrugineum Ridl. by P.F. Stevens during his review of the materials deposited at SING for his revision of the genus (Fig. 1). We were also unable to confirm the record in Chew et al. (1997) as there are no voucher specimens available. There were also no collections cited for the conservation assessment by Tan et al. (2008). Moreover, Stevens (1980) only treated Calophyllum spectabile auct. non Willd. sensu Ridley (1922) to be C. soulattri in part. Hence, it is unclear as to which part of the heterogeneous taxon refers to Calophyllum soulattri. The specimens annotated "Wallich Cat. no. 4843" and collected from Singapore and Penang were cited by Ridley (1922) but found by Planchon \& Triana (1861) to be a mixed collection comprising several species. These species are Calophyllum spectabile ( $=$ C. soulattri) of an unknown origin, Calophyllum lanigerum Miq. var. austrocoriaceum (Whitmore) P.F.Stevens probably from Singapore, and predominantly $C$. wallichianum var. wallichianum from Penang. Therefore, Stevens (1980) could have been referring to the element without an origin when he placed a part of $C$. spectabile auct. non Willd. sensu Ridley (1922) under the synonymy of C. soulattri. The lack of verifiable records and apparent misunderstandings of earlier literature beginning with Keng (1990), lead us to conclude that there is no evidence that Calophyllum soulattri is found in the forests of Singapore. 


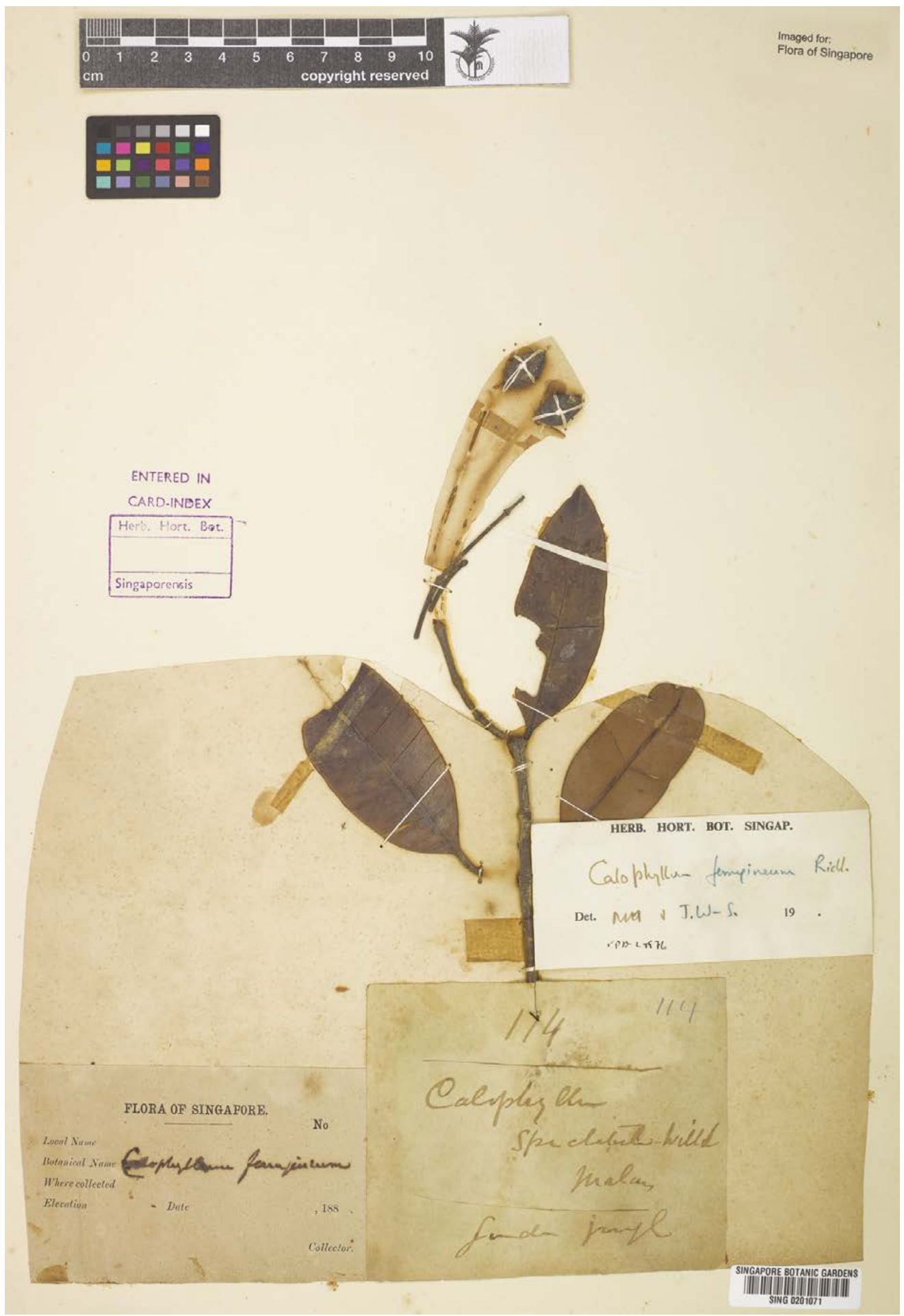

Fig. 1. Historical herbarium specimen of Calophyllum ferrugineum, Unknown s.n. [SING0201071], originally labelled as Calophyllum spectabile and later re-determined by M.R. Henderson \& J. Wyatt-Smith and agreed by P.F. Stevens. 


\section{Calophyllum wallichianum var. wallichianum, a misapplied name in Singapore}

The first comprehensive review of Calophyllum for the Malayan region was conducted by Henderson \& Wyatt-Smith (1956). In the account, Calophyllum wallichianum was considered as having two distinguishable regional forms: northwestern (Kedah, Penang, and Perak) and southern (Terengganu, Pahang, Johor, and Singapore). Specimens from the northwestern population were described as having an ovate leaf shape (broadest at the base), milky exudates, as well as sparsely hairy terminal buds and young twigs, while those from the southern population have an oblong-lanceolate (more or less uniform throughout) leaf shape, clear golden exudates as well as hairier terminal buds and young twigs. The former also has curved terminal buds while the latter has straight ones. Henderson \& Wyatt-Smith (1956) initially decided to recognise the two forms as different species and drafted the name Calophyllum rufigemmatum for the southern form. However, upon surveying more materials, they concluded that there was insufficient support for their decision and regarded the species as highly variable. Whitmore (1973) followed their views and also recognised the two populations of Calophyllum wallichianum as a single species with much variation.

Later, Stevens (1980) observed further differences between the two regional forms of Calophyllum wallichianum. He noticed that the northwestern population had smaller fruits $(2-3(-3.5) \mathrm{cm}$ long) and thinner stone walls $(0.3-1.1 \mathrm{~mm})$ while the southern population had larger fruits $((2.6-) 3-4.4 \mathrm{~cm}$ long) and thicker stone walls ((1-)1.3-2 mm). Both groups also have distinctive hair types. Therefore, Stevens (1980) proposed that they be recognised as different species. He stated that the name Calophyllum wallichianum must apply to the northwestern population as the fruit sizes of the type specimen of this species and the collections match. The name Calophyllum rufigemmatum was then proposed for the southern population and a collection from Singapore was chosen as the type. While reviewing the Calophyllum wallichianum complex, Stevens (1980) also reduced the taxon C. incrassatum M.R.Hend. \& Wyatt$\mathrm{Sm}$. to a variety of $C$. wallichianum. Despite the conclusions of Stevens (1980), it appears that during his visit to SING in 1976, he was undecided as to whether the two populations were indeed different species. A number of specimens collected from Singapore were determined by Stevens in 1976 as Calophyllum wallichianum but the same specimens were later cited by Stevens (1980) under C. rufigemmatum (Fig. 2). These specimens are: Corner SFN 34546 [SING0201748], Bukit Timah; Kiah SFN 39451 [SING0017938, SING0017940, SING0017945], Gardens Jungle and Sinclair SFN 39605 [SING0017943], Mandai Forest.

Several authors who worked on the Singapore flora after Stevens (1980) accepted his concept of Calophyllum wallichianum var. incrassatum and C. rufigemmatum (Keng, 1990; Turner 1993, 1997). However, other authors, such as LaFrankie et al. (2005), Tan et al. (2008) and Chong et al. (2009), appear to have misunderstood the Stevens (1980) concept of Calophyllum wallichianum. LaFrankie et al. (2005) regarded Calophyllum wallichianum and $C$. incrassatum as distinct species and included both in their publication on the forest trees of Bukit Timah Nature Reserve. Calophyllum wallichianum sensu LaFrankie et al. (2005) was stated to have fruits that 


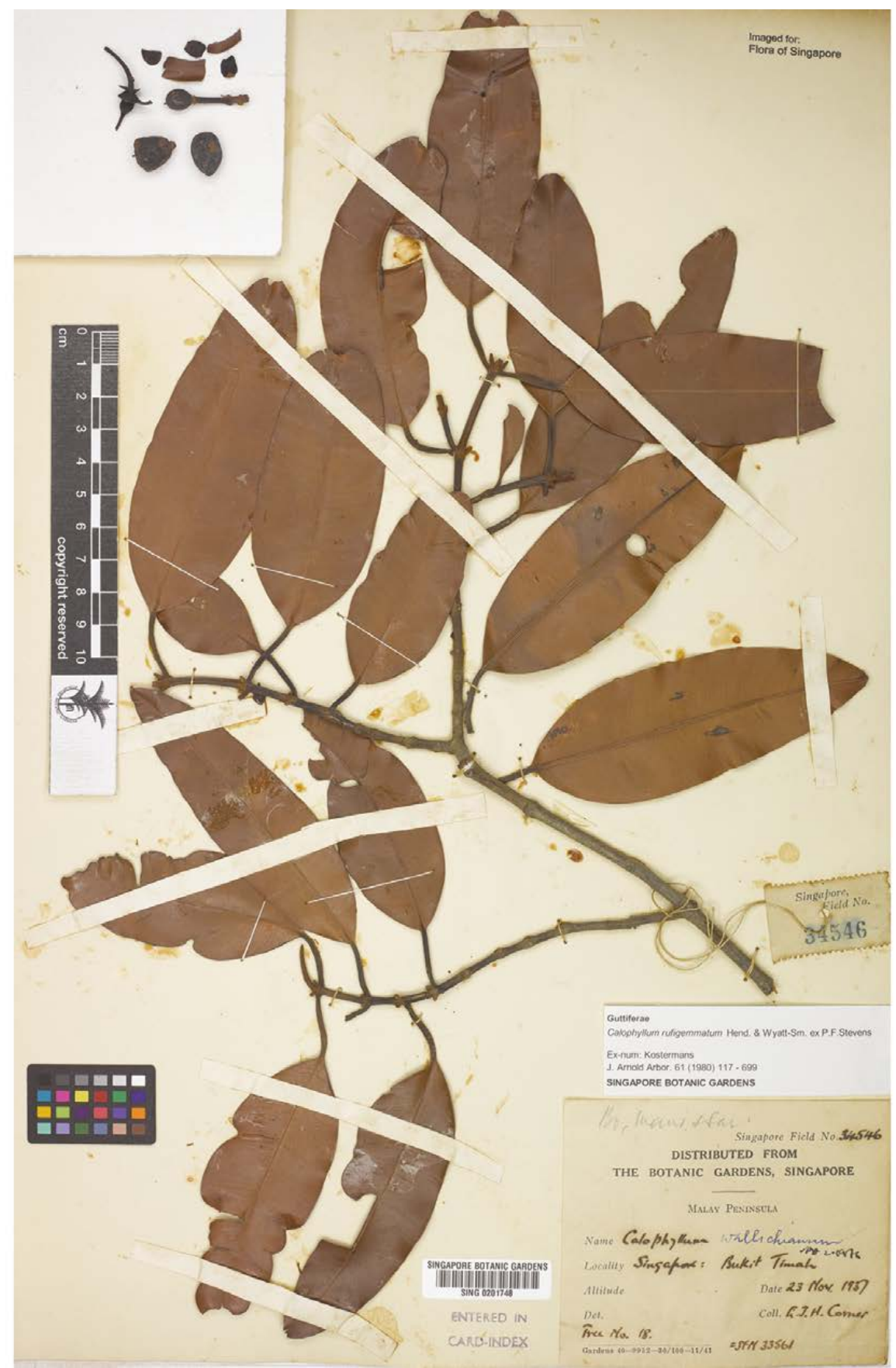

Fig. 2. Herbarium specimen of Calophyllum rufigemmatum, Corner SFN34546 [SING0201748]. Note the signature of P.F. Stevens (dated 1976) beside the determination of Calophyllum wallichianum on the original label (a practice now strongly discouraged - rather a new label should be appended). 
are $4 \mathrm{~cm}$ long, which match the measurements of $C$. rufigemmatum fruits described by Stevens (1980), and the specimens deposited at SING. The voucher specimens cited by LaFrankie et al. (2005) and held at the Asian School of the Environment, College of Science, Nanyang Technological University (NTU) have been checked and confirmed as being Calophyllum rufigemmatum. Tan et al. (2008) assessed Calophyllum wallichianum var. wallichianum, the typical variety of the species, as nationally Critically Endangered, Calophyllum wallichianum var. incrassatum as nationally Vulnerable, and C. rufigemmatum as nationally Endangered. Chong et al. (2009) followed suit and included these taxa in their checklist of the vascular plants of Singapore. They considered Calophyllum wallichianum sensu Lafrankie et al. (2005) to be distinct from C. rufigemmatum and, updating the nomenclature, thus included both C. wallichianum var. wallichianum and C. wallichianum var. incrassatum, in addition to C. rufigemmatum, for Singapore. However, only Calophyllum wallichianum var. incrassatum is known to occur in Singapore as LaFrankie's $C$. wallichianum is $C$. rufigemmatum.

ACKNOWLEDGEMENTS. This work was conducted as part of the Nee Soon Swamp Forest Biodiversity and Hydrology Baseline Studies-Phase 2 Project and the Flora of Singapore Project. We thank the past and present members of the BoTANy Laboratory at the National University of Singapore and staff at the Singapore Botanic Gardens Herbarium for their assistance. We acknowledge Derek Liew for providing digital scans of some specimens. We are grateful to Dr Shawn Lum and Dr Ngo Kang Min for facilitating our visit to the Asian School of the Environment, College of Science, at the Nanyang Technological University (NTU). Dr Peter Stevens and Dr David Middleton are thanked for their helpful feedback.

\section{References}

APG III (2009). An update of the Angiosperm Phylogeny Group classification for the orders and families of flowering plants: APG III. Bot. J. Linn. Soc. 161: 105-121.

Chew, P.T., Saifuddin Suran \& Ali Ibrahim (1997). Checklist of Vascular Plants in the Nature Reserves of Singapore. Gard. Bull. Singapore 49: 161-223.

Chong, K.Y., Tan, H.T.W. \& Corlett, R.T. (2009). A Checklist of the Total Vascular Plant Flora of Singapore: Native, Naturalised and Cultivated Species. Singapore: Raffles Museum of Biodiversity Research, National University of Singapore.

Henderson, M.R. \& Wyatt-Smith, J. (1956). Calophyllum Linn. Gard. Bull. Singapore 15: $285-375$.

Keng, H. (1990). Calophyllum. In: The Concise Flora of Singapore: Gymnosperms and Dicotyledons, p. 48. Singapore: Singapore University Press.

LaFrankie, J.V., Davies, S.J., Wang, L.K., Lee, S.K. \& Lum, S.K.Y. (2005). Forest trees of Bukit Timah: Population ecology in a tropical forest fragment. Singapore: Simply Green.

Planchon, J.E. \& Triana, J.J. (1861). Mémoire sur la famille des Guttifères. Ann. Sci. Nat., Bot. 15: 277-278.

Ramesh B.R., Ayyappan, N. \& De Franceschi, D. (2012). Calophyllum pascalianum, a new species of Clusiaceae from Western Ghats, India. Kew Bull. 67(1): 115-118. 
Ridley, H.N. (1900). The Flora of Singapore. J. Straits Branch Roy. Asiat. Soc. 33: 27-196.

Ridley, H.N. (1922). Calophyllum L. In: The Flora of the Malay Peninsula, vol. 1, Polypetalae, pp. 181-188. London: L. Reeve \& Co., Ltd.

Stevens, P.F. (1980). A Revision of the Old World Species of Calophyllum (Guttiferae). J. Arnold Arbor. 61(2): 117-424.

Stevens, P.F. (2001 onwards). Angiosperm Phylogeny Website, ver. 14, July 2017 [and more or less continuously updated since]. http://www.mobot.org/MOBOT/research/APweb/. Accessed 21 Jan. 2019.

Tan, H.T.W., Tan, K.-X., Ali bin Ibrahim, Chew, P.T., Chua, K.S., Duistermaat, H., Ganesan, S.K., Goh, M.W.K., Gwee, A.T., Kiew, R., Lee, S.M.L., Leong, P., Lim, J., Lok, A.F.S.L., Loo, A.H.B., Lum, S.K.Y., Morgany Thangavelu, Saifuddin bin Suran, Sim, S., Samsuri Ahmad, Wee, Y.C., Yap, K.F., Yeo, C.K. \& Yong, J.W.H. (2008). Seed plants. In: Davison, G.W.H., Ng, P.K.L. \& Ho, H.C. (eds) The Singapore Red Data Book: Threatened plants and animals of Singapore, 2nd ed., pp. 213-244. Singapore: The Nature Society (Singapore).

Thiers, B. (continuously updated). Index Herbariorum: A global directory of public herbaria and associated staff. New York Botanical Garden's Virtual Herbarium. http://sweetgum. nybg.org/ih/. Accessed 27 Mar. 2019.

Turner, I.M. (1993). The Names Used for Singapore Plants Since 1900. Gard. Bull. Singapore 45: $1-287$.

Turner, I.M. (1997 ['1995']). A Catalogue of the Vascular Plants of Malaya. Gard. Bull. Singapore 47: 1-757.

Whitmore, T.C. (1973). Guttiferae. In: Whitmore, T.C. (ed) Tree Flora of Malaya, A Manual for Foresters, vol. 2, pp. 162-236. Malaysia: Longman.

Wurdack, K.J. \& Davis, C.C. (2009). Malpighiales Phylogenetics: Gaining ground on one of the most recalcitrant clades in the angiosperm tree of life. Amer. J. Bot. 96(8): 15511570. 